Case Reports in
Gastroenterology
Case Rep Gastroenterol 2020;14:420-425

DOI: $10.1159 / 000508437$

Published online: August 26, 2020

(C) 2020 The Author(s)

Published by S. Karger AG, Basel www.karger.com/crg

This article is licensed under the Creative Commons Attribution-NonCommercial 4.0 International License (CC BY-NC) (http://www.karger.com/Services/OpenAccessLicense). Usage and distribution for commercial purposes requires written permission.

\title{
Rectal Prolapse Concomitant with Uterovaginal Prolapse Protects the Ileum from Necrosis in Transanal Ileum Evisceration through a Traumatic Tear on the Sigmoid Wall
}

\author{
Vicky Sumarki Budipramana Deddy Aryanda Putra \\ Department of Surgery, Faculty of Medicine, Universitas Airlangga/Dr. Soetomo General \\ Hospital, Surabaya, Indonesia
}

\section{Keywords}

Evisceration of the ileum · Cardinal uterosacral ligament · Necrosis

\begin{abstract}
Eviscerated ileum passing through a traumatic tear on the sigmoid wall is a rare case and all the cases reported previously showed that the eviscerated intestines were necrotic. However, in this case, although the huge size of eviscerated intestine had already exceeded the intestinal ischemic time, the small intestine outside the anus was not necrotic. Here we report the case of a 73-year-old female who presented with evisceration of the small intestine out of her anus as long as $200 \mathrm{~cm} 7 \mathrm{~h}$ before. The eviscerated small intestine (ileum) appeared still viable and there were no signs of pain, obstruction, or peritonitis. An intermittent rectal concomitant with uterovaginal prolapse had been experienced by the patient before. On surgery, the ileum was not necrotic and pulled back out of the sigmoid wall tear. The cardinal uterosacral ligament may have an important role in maintaining the uterovagina in place. When this ligament loses its ability to anchor the uterovagina to the sacrum, both the uterovagina and the rectum will lose their fixation to the sacrum and prolapse will occur. Hence, the rectum located posterior to the uterovagina also relieves its squeeze pressure so that it will not disrupt the blood supply of the ileum when the ileum enters through the rectal lumen. Rectal concomitant with
\end{abstract}




\section{Case Reports in Gastroenterology}

Case Rep Gastroenterol 2020;14:420-425 DOI: $10.1159 / 000508437$

(c) 2020 The Author(s). Published by S. Karger AG, Basel www.karger.com/crg

Budipramana and Putra: Rectal and Uterovaginal Prolapse Protects the Eviscerated lleum from Necrosis

uterovaginal prolapse is an important factor to maintain the viability of the eviscerated intestine. Therefore, surgeons are still able to make better preparation before performing surgery.

(C) 2020 The Author(s)

Published by S. Karger AG, Basel

\section{Introduction}

We present a rare case in whom a small intestinal (ileum) evisceration occurred after minor trauma. The ileum entered through a tear of the sigmoid (Fig. 1) and went out of the anus. The part of ileum that went out through the anus was not strangulated and still looked pinkish due to the laxity of the cardinal uterosacral ligament (Fig. 2) and the rectal prolapse concomitant with uterovaginal prolapse having been suffered before.

The patient has had a history of concurrent rectal and uterovaginal prolapse for 3 years. Pelvic floor weakness caused by repeated pregnancies and childbirth predisposed to the occurrence of small intestine evisceration [1]. In this case, the eviscerated ileum that went out of the anus did not experience strangulation, in contrast to the intestinal necrosis in some cases reported previously; there had been no history of rectal prolapse before.

The cardinal uterosacral ligament may have an important role when it loses its ability to anchor the uterovagina in place; the uterovaginal concomitant with rectum will lose their fixation to the sacrum and prolapse will occur [2].

\section{Case Presentation}

A 73-year-old woman who had had a 3-year history of concomitant rectal and vaginal prolapse came to the hospital with the chief complaint of a huge part of her bowels suddenly coming out of her anus. There was a pinkish bowel coming out $7 \mathrm{~h}$ before. By coughing, the bowel outside became longer and longer over time until it reached the size of $200 \mathrm{~cm}$. It occurred to the patient who had fallen down on the floor in a sitting position. There was no severe abdominal pain and no history of repeated episodes of colicky pain, as usually happens in intussusception case [3].

On physical examination, an evisceration of small bowel was seen and so was vaginal prolapse (Fig. 3). The patient had a weak general state, no bowel sounds, no muscular rigidity, and no general peritonitis. The length of the bowel that went out of the anus was around $200 \mathrm{~cm}$ and it was not necrotic. Surgery was performed through midline incision, and the surgeon found the small bowel entering a tear defect on the sigmoid wall. Around $10 \mathrm{~mL}$ of peritoneal fluid mixed with fecal materials was found in the surrounding ruptured area. A redundant sigmoid was also found and the eviscerated ileum was still viable and was gently pulled out of the defect on the sigmoid wall until all the eviscerated ileum was repositioned into the abdominal cavity. The rupture of the sigmoid wall was stitched using primary suture and brought out as a loop sigmoidostomy for safety. The patient was allowed to go home on the 5 th day and after 30 days the patient had recovered uneventfully.

\section{Discussion}

The first small bowel evisceration ever reported was by Brodie in 1827 [4]. In 70 cases reported in literatures, rectal prolapse was a predisposing factor that was often related to 


\section{Case Reports in Gastroenterology}

Case Rep Gastroenterol 2020;14:420-425

DOI: 10.1159/000508437

(c) 2020 The Author(s). Published by S. Karger AG, Basel www.karger.com/crg

Budipramana and Putra: Rectal and Uterovaginal Prolapse Protects the Eviscerated lleum from Necrosis

ischemia, presumably caused by the pelvic musculature pressure on the prolapsed rectum [5, 6]. Within $6 \mathrm{~h}$ of intestinal ischemic time, acute complete disruption of the intestinal blood supply leads to irreversible mucosal ischemia with cellular energy loss and leukocyte infiltration, accompanied by the formation of oxygen radicals [7].

Management of transanal small bowel evisceration depends on the viability of the eviscerated bowels and contamination of the peritoneal cavity, the patient's general state, and comorbidities [8]. The standard management for this condition is exploration laparotomy with reduction of the eviscerated bowel back to the abdominal cavity, with or without resection. Only one case of successful treatment with laparoscopic technique is reported [9]. In 2010, a case of failure in reducing transanal small bowel evisceration using manual digital reduction from outside was reported; digital reduction should not be performed even in chronic rectal prolapse cases as it will cause perforation of the rectum. The reduction of the eviscerated intestine should be performed at the time of laparotomy [10]. Transanal gut evisceration is a life-threatening condition, the estimated mortality rate was reported to be around $42 \%$ [4].

The diagnosis of transanal ileum evisceration through a tear defect on other intestinal wall is not easy as it mimics an intestinal intussusception or rectal prolapse coming out of the anus used to be experienced by the patient, and moreover, the patient does not feel any signs of pain, bowel obstruction, or peritonitis. The diagnosis was made based on the fact that it was preceded by a sudden increase in intrabdominal pressure caused by falling down in a sitting position and that there was no severe abdominal pain, no history of repeated episodes of colicky pain, and no intermittent abdominal pain. Thus, there was no suspicion of intussusception in this patient. Although the patient had experienced an intermittent rectal prolapse before, the surgeon did not think that it was the case, because the eviscerated intestine was very long, $200 \mathrm{~cm}$ outside the anus, and this was unlikely to occur in rectal prolapse. This pathological condition often occurs in elderly patients and usually occurs spontaneously [5, 6], but in this case it was preceded by minor trauma (slipping while walking). Sudden increase in abdominal pressure may be one of the etiologies of transanal bowel evisceration.

There was no sign of peritonitis, perhaps due to minimal fecal contamination from the sigmoid wall defect because the defect was directly closed by the ileum that passed into the sigmoid defect.

Our patient had had a 3-year history of concurrent rectal and uterovaginal prolapse. The pelvic floor weakness caused by repeated pregnancies and childbirth predisposed to the occurrence of small intestine evisceration [1]. In this case, the eviscerated ileum that went out of the anus did not experience strangulation, in contrast to the intestinal necrosis in some cases previously reported where there had been no history of rectal prolapse. The strangulation of the transanal eviscerated ileum might be due to the squeeze pressure made by the pelvic musculature and anal sphincter to the ileum that eviscerated. The tear defect on the sigmoid wall was too loose to strangulate the ileum passing through it.

The major support of the pelvic organ is by the levator ani muscles, pelvic connective tissue, and the vaginal walls, and defects in these structures result in the genesis of pelvic floor dysfunction. Although the etiology of pelvic organ prolapse is multifactorial, vaginal delivery is known as the strongest risk factor by many epidemiological studies [11]. The pelvic floor disorders often develop as a result of a spontaneous unsupervised delivery [12] or repeated pregnancies and childbirths causing stretching and tearing of the endopelvic fascia, levator ani muscles, and perineal body $[12,13]$. The rarer cases are the connective tissue disorder, and Ehlers-Danlos syndrome is also associated with uterovaginal and/or rectal prolapse [14]. 


\section{Case Reports in Gastroenterology}

\begin{tabular}{l|l}
\hline Case Rep Gastroenterol 2020;14:420-425 \\
\hline DOI: 10.1159/000508437 & $\begin{array}{l}\text { ○ 2020 The Author(s). Published by S. Karger AG, Basel } \\
\text { www.karger.com/crg }\end{array}$ \\
\hline
\end{tabular}

Budipramana and Putra: Rectal and Uterovaginal Prolapse Protects the Eviscerated Ileum from Necrosis

At the time the patient came to the emergency room, the eviscerated intestine was around $100 \mathrm{~cm}$ in length, however, because of repeated coughing it became longer and longer until it reached the length of $200 \mathrm{~cm}$. This showed that the pelvic muscle was very flaccid, and in this situation necrosis of the small intestine was not expected.

Corduk et al. [5] reported one case where more than half of the small intestine eviscerated through the anus via a longitudinal anterior laceration of the sigmoid colon and a large mesenteric defect. It was not because of the laxity of the pelvic muscle, but because of the very huge blunt abdominal trauma, hence causing bilateral diaphragmatic rupture and spinal cord injury. However, in this case, the trauma was relatively mild as the patient just fell down on the floor in a sitting position, but because of the laxity of the pelvic floor muscle even the large size of small intestine eviscerated.

The cardinal uterosacral ligament may have an important role in maintaining the uterovagina in place. When this ligament loses its ability to anchor the uterovagina in place because of unsupervised childbirths, the uterovaginal concomitant with rectum will lose their fixation to the sacrum and prolapse will occur. Thus, the rectum located posterior to the uterovagina also relieves its squeeze pressure and does not disrupt the blood supply of the ileum entering the rectal lumen. However, if the prolapse only occurs in the rectum alone, the squeeze pressure of the cardinal uterosacral ligament to the rectum still exists and it is still able to press the blood supply of the intestine passing in through it and necrosis will occur. This situation can explain the fact that despite the very huge length of the small intestine eviscerating through the anal canal (around $200 \mathrm{~cm}$ ) there was still not necrosis.

\section{Conclusion}

The intermittent rectal concomitant with uterovaginal prolapse experienced by the patient before, caused by the laxity of the cardinal uterosacral ligament, is an important factor to maintain the eviscerated intestine still viable although it exceeds the intestinal ischemic time. Therefore, surgeons are still able to make better preparation before performing surgery.

\section{Statement of Ethics}

Written informed consent to publish the case anonymously (including publication of images) was obtained from the patient.

\section{Conflict of Interest Statement}

The authors have no conflicts of interest to declare.

\section{Funding Sources}

No funding was obtained for this case report. 


\section{Case Reports in Gastroenterology}

\section{Author Contributions}

V.S. Budipramana wrote, reviewed, and edited the manuscript. D.A. Putra collected the patient data and obtained informed consent from the patient.

\section{References}

1 Steele SR, Hull TL, Read TE, Saclarides TJ, Senagore AJ, Whitlow CB, editors. The ASCRS Textbook of Colon and Rectal Surgery. 3rd ed. Cham: Springer International Publishing; 2016.

2 Wolman l. Berek and Novak's Gynecology 15th Edition. J Obstet Gynecol India. 2014 Apr;64(2):150-1.

3 Ochiai H, Ohishi T, Seki S, Tokuyama J, Osumi K, Urakami H, et al. Prolapse of Intussusception through the Anus as a Result of Sigmoid Colon Cancer. Case Rep Gastroenterol. 2010 Sep;4(3):346-50.

4 Morris AM, Setty SP, Standage BA, Hansen PD. Acute transanal evisceration of the small bowel: report of a case and review of the literature. Dis Colon Rectum. 2003 Sep;46(9):1280-3.

5 Corduk N, Koltuksuz U, Karabul M, Savran B, Bagci S, Sarioglu-Buke A. A rare presentation of crush injury: transanal small bowel evisceration. Case report and review of the literature. Pediatr Surg Int. 2011 Sep; 27(9):1021-4.

6 Bhat S, Azad TP, Kaur M. Spontaneous perforation of rectum with evisceration of small bowel simulating intussusception. N Am J Med Sci. 2010 Dec;2(12):596-7.

7 Klar E, Rahmanian PB, Bücker A, Hauenstein K, Jauch KW, Luther B. Acute mesenteric ischemia: a vascular emergency. Dtsch Arztebl Int. 2012 Apr;109(14):249-56.

8 Jeong J, Park JS, Byun CG, Yoon DS, Sohn SK, Lee YH, et al. Rupture of the rectosigmoid colon with evisceration of the small bowel through the anus. Yonsei Med J. 2000 Apr;41(2):289-92.

9 Antony MT, Memon MA. Successful laparoscopic repair of spontaneous rectosigmoid rupture with an acute transanal small bowel evisceration. Surg Laparosc Endosc Percutan Tech. 2005 Jun;15(3):172-3.

10 Trinidade A, Shakeel M, Jehan S. Transanal small bowel evisceration following digital reduction of a chronically prolapsing rectum. J Coll Physicians Surg Pak. 2010 Nov;20(11):760-2.

11 Razzak L. Pathophysiology of pelvic organ prolapse. IntechOpen. doi: 10.5772/intechopen.76629. Available from: https://www.intechopen.com/books/pelvic-floor-disorders/pathophysiology-of-pelvic-organprolapse.

12 Umeh UA, Ugwu EO, Obi SN, Nnagbo JE. Concurrent Occurrence of Uterovaginal and Rectal Prolapse: An Uncommon Presentation. Ann Med Health Sci Res. 2015 Sep-0ct;5(5):365-7.

13 Karateke A, Batu P, Asoğlu MR, Selçuk S, Cam C. Approach to concomitant rectal and uterine prolapse: case report. J Turk Ger Gynecol Assoc. 2012 Mar;13(1):70-3.

14 Sun C, Hull T, Ozuner G. Risk factors and clinical characteristics of rectal prolapse in young patients. J Visc Surg. 2014 Dec;151(6):425-9. 
Case Reports in Gastroenterology
Case Rep Gastroenterol 2020;14:420-425

DOI: $10.1159 / 000508437$

(c) 2020 The Author(s). Published by S. Karger AG, Basel www.karger.com/crg

Budipramana and Putra: Rectal and Uterovaginal Prolapse Protects the Eviscerated lleum from Necrosis

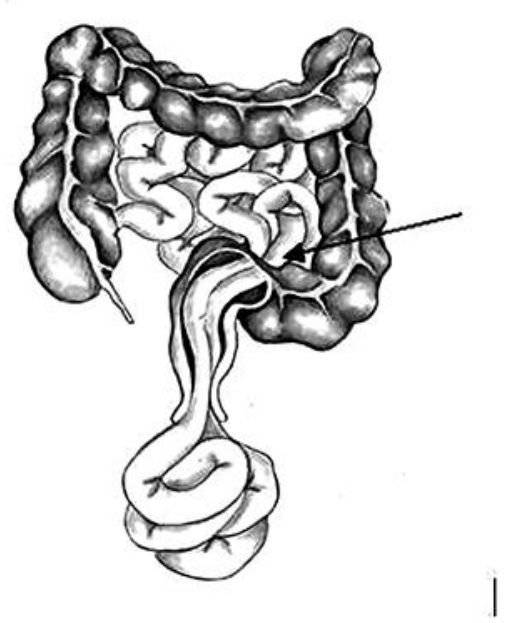

Fig. 1. Illustration of the transanal ileum evisceration through the sigmoid defect (arrow).

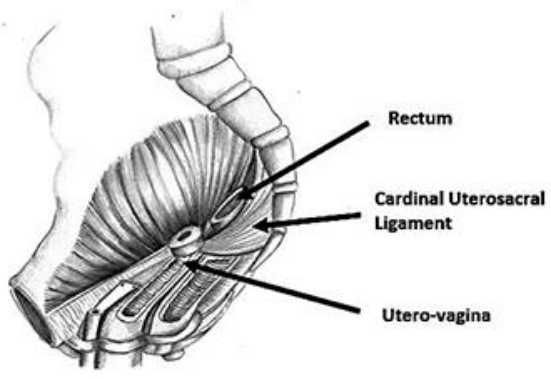

Fig. 2. The cardinal uterosacral ligament maintaining the uterovagina in place and holding the rectum.

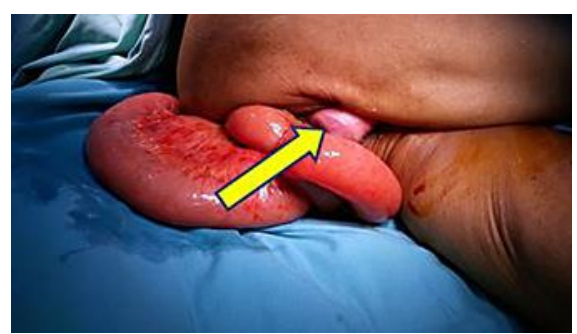

Fig. 3. Ileum evisceration concomitant with uterovaginal prolapse (arrow). 